\section{COCONUT OIL INHIBITS CARIES}

Scientists from Ireland have shown that digested coconut oil can attack the bacteria that cause caries. Coconut oil is a natural antibiotic and could be incorporated into commercial dental care products.

A research team from the Athlone Institute of Technology tested the antibacterial action of coconut oil in its natural state and coconut oil that had been treated with enzymes, in a process similar to digestion. The oils were tested against strains of Streptococcus bacteria. They found that enzymemodified coconut

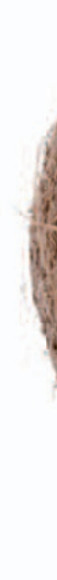

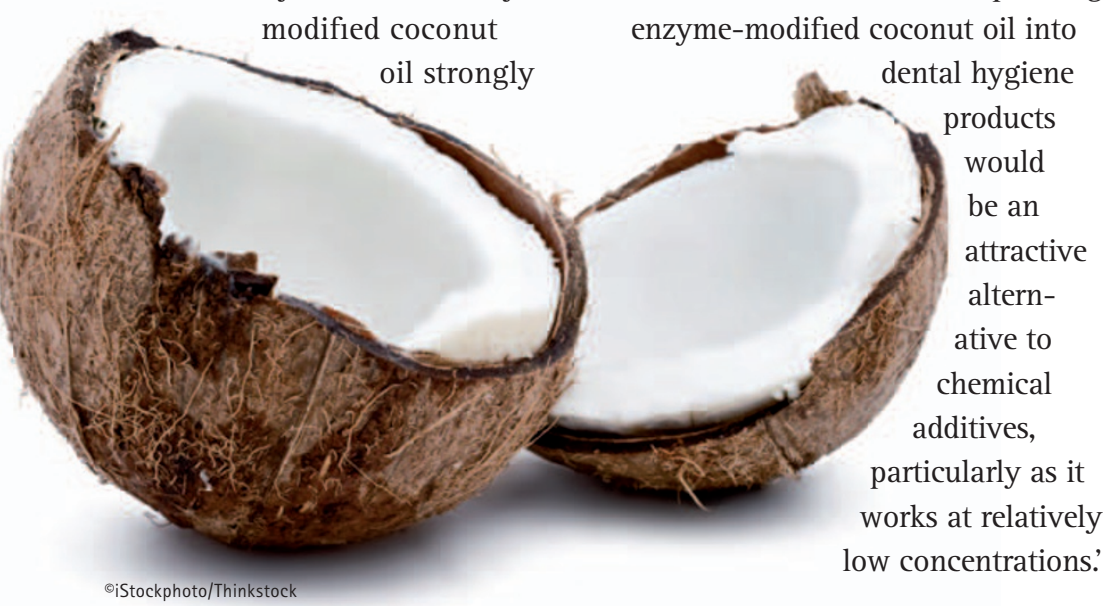

\section{NEW PROTEIN CAPSULE FIGHTS GUM DISEASE}

A new injectable, controlledrelease capsule has been designed by US scientists to fight gum disease. Targeting inflammation rather than the bacteria that start the disease, the capsule releases a protein which helps the body fight the disease and allows healthy tissue to grow in its place.

Injected into pockets between the gums and teeth, this approach uses the excreted protein to guide specialised white blood cells to the specific infected site. The white blood cells, lymphocytes, help to restore immune balance and maintain homeostasis.

The research, presented by Steven Little from the University of Pittsburgh at the 244th National Meeting and Exposition of the American Chemical Society inhibited the growth of most strains of Streptococcus bacteria including Streptococcus mutans a major cause of caries.

The group, who presented their work at the Society for General Microbiology's autumn conference at the University of Warwick, were prompted to investigate the effect of enzyme-modified foods on bacteria after many previous studies showed that partially digested foodstuffs are active against microorganisms.

Dr Damien Brady, the lead researcher, remarked: 'Incorporating enzyme-modified coconut oil into ow concentrations.' in Philadelphia in August, showed that positive results had been achieved in mice. Symptoms of disease had significantly diminished and conditions favourable for the regrowth of gum tissue had developed. The dissolvable polymer material forming the capsule is used in medicine and the protein, a chemokine, is already naturally produced by the body, indicating the treatment would be successful in humans.

With $83 \%$ of the UK population affected by gum disease, ${ }^{1}$ the capsule could have a great impact on oral health.

1. Steele J, O'Sullivan I. Executive summary: Adult Dental Health Survey 2009. London: The NHS Information Centre, 2011.

By Laura Pacey

\section{HONOURS, AWARDS, APPOINTMENTS}

Royal Garden Party

Roger Bell, a Life Member of the British Dental Association (BDA) was recently invited to a Royal Garden Party in recognition of services to railway heritage. Roger was the prime mover in the restoration of the steam locomotive named Princess Elizabeth, a Stanier Pacific which hauled the Royal Train carrying Her Majesty Queen Elizabeth II on 11 July 2012 on part of her Diamond Jubilee tour from Newport to Hereford and later in the day from Worcester to Oxford.

\section{First PhD}

Dr Chris Fox is the first person to achieve a PhD at the Peninsula Dental School (PDS), Plymouth University, five years after PDS opened its doors to students. Dr Fox achieved her PhD with research commissioned by the Shirley Glasstone Hughes Trust (SGHT). The study evaluated SGHT's research agenda-setting process in order to help the Trust successfully complete a trial of a new approach to its work.

\section{BDA PEC}

Dr Stephen Shimberg is the final person to be elected to serve as a member of the BDA's Principal Executive Committee (PEC). Dr Shimberg won a closely-contested by-election in the North-West of England.

\section{Spearheading innovation}

Professor Nigel Pitts and Dr Christopher Longbottom have been appointed at King's College London Dental Institute to spearhead a new focus on dental innovation, the translation of research into clinical practice, public policy, and the commercialisation of research in order to improve health and healthcare. They will join the Institute in early 2013 and develop a new Dental Innovation and Translation Centre (Dental ITC).

\section{Restorative appointment}

Ewen McCool has been appointed Associate Professor and Consultant in Restorative Dentistry at the Peninsula Dental School's Devonport Dental Education Facility.

\section{Doctoral research fellowship}

Barry Main, a lecturer and specialist registrar in oral and maxillofacial surgery, has been awarded a doctoral research fellowship funded by the National Institute for Health Research (NIHR). Dr Main will investigate current practice and standards of consent for patients undergoing surgery for oral cancer.

\section{PATIENT INDEMNITY FACT SHEET}

The General Dental Council (GDC) has produced a new fact sheet for patients to help them understand their dental professional's indemnity responsibilities.

The new fact sheet guides patients through what they should do if something does go wrong.

www.gdc-uk.org/Membersofpublic/Documents/ Indemnity\%20patient\%20information \%20FINAL \%20 August\%202012.pdf. 